\title{
Biodiesel Production from Dry Microalga Biomass by Microwave-Assisted In-Situ Transesterification
}

\author{
Lailatul Qadariyah", Mahfud, Renova Panjaitan, Fatkhulloh Mujaddid, and Ummu Kalsum \\ Department of Chemical Engineering, Institut Teknologi Sepuluh Nopember, Sukolilo 60111 Surabaya Indonesia
}

\begin{abstract}
Microalga is one of the potential feedstocks in the manufacture of biodiesel because it contains high oil content. In this study, Chlorella $s p$. was selected because its high oil content about $28-32 \%$ of oil (based on its dry weight) and its presence is abundant among other green algae. In situ transesterification was carried out in round neck flask under microwave irradiation. Microwave irradiation can facilitate the in situ transesterification by extracted the lipid of microalga and simultaneous convert to FAME. The purposes of this study are to investigate the effect of acid catalyst concentration, microwave power, reaction time and the addition of cosolvent (n-hexane) on the yield of biodiesel, to get optimum operating conditions and to know the fatty acid compounds of biodiesel from Chlorella $s p$. The results of oil extraction and biodiesel were analyzed by GC-MS analysis. Based on the experiment, the yield of microalga oil was $11.37 \%$. The optimum yield of biodiesel by in-situ transesterification was $75.68 \%$. It was obtained at the microwave power of 450 watts, the reaction time of 60 minutes, an acid catalyst concentration of $0,2 \mathrm{M}$ of $\mathrm{H}_{2} \mathrm{SO}_{4}$, and the co-solvent addition of $10 \mathrm{ml}$.
\end{abstract}

\section{Introduce}

Nowadays, a lot of research was done on produce alternative fuel called biodiesel. Biodiesel is made from vegetable oil and animal fat. However, the lack of produce biodiesel from vegetable oil is it competes with food and has a long harvesting time [1]. Whereas, biodiesel from animal fat has less quality [2]. One of the natural resources that potential be the raw material of biodiesel is microalga. Microalga has fast growth and contains a lot of lipids. Harvesting of microalga can be done every day [3]. Microalga is the fastest organism in photosynthesis and contains high lipid content. It can produce yield up to 200 times more than other plants [4].Triglycerides which is contained in microalga can easily be extracted and transesterified to get biodiesel [5]. This research used microalga Chlorella $s p$. as the main material. Chlorella $s p$. contains $28-32 \%$ of \% lipid based on its dry weight [3].

Generally, biodiesel usually produced using ex situ transesterification, that is extraction lipid of microalga continued by transesterification process. But, this process is uneconomical and take a long reaction time. This process also needs higher of temperature and has a slow rate of reaction. Besides it, this process needs the higher amount of solvent and impossible to do a scale-up [6]. To resolve it, now there has been developed a nonconventional method called in situ transesterification. In situ transesterification is a simple method to produce biodiesel. This process cuts the extraction and purification step of microalga oil [7]. Microwave irradiation is one of the new technology in extract the lipid of microalga. It has been reported that microwave is a simple and effective technology for extraction the lipid of microalga. Heating by microwave can help to speed up the extraction and simultaneously turn it into FAEE or FAME [6]. Microwave irradiation has been applied in the transesterification of Chlorella protothecoides oil by Azcan et al.[8]. Transesterification by conventional heating was done in the molar ratio of oil to methanol of $1: 8$, catalyst concentration about $1 \%$, the reaction time of 210 minutes and temperature reaction of $65^{\circ} \mathrm{C} .96 .94 \%$ of $\%$ biodiesel conversion was obtained by this condition while the transesterification by microwave in the molar ratio of oil to methanol of $1: 8$, catalyst concentration about $1 \%$, the reaction time of 5 minutes was $96,54 \%$. According to this research, use microwave can decrease the reaction time and save the energy. Another experiment has been explained by Dianursanti et al. [9]. They confirmed that the addition of co-solvent is also considered as a way to increase the yield on in situ transesterification because co-solvent can increase the solubility of alcohol and speed up the in situ transesterification.

This paper concerns with the development of in situ transesterification of Chlorella sp. using microwave

Corresponding author: lailatul_2008@yahoo.com 
irradiation. The purposes of this experiments were to investigate the effect of acid catalyst concentration, microwave power, reaction time and the addition of cosolvent (n-hexane) on the yield of biodiesel, to get optimum operating conditions and to know FAME compounds of biodiesel from Chlorella sp. This work was expected to produce a high yield of biodiesel and expected that methyl ester compounds of biodiesel are suitable for making a good biodiesel.

\section{Methods}

\subsection{Materials}

The main materials that use in this research were powder of microalga Chlorella sp., which was collected from BBAP Jepara, Methanol 96\%, n-hexane $96 \%$ and the acid catalyst was $\mathrm{H}_{2} \mathrm{SO}_{4} 98 \%$ of $\%$ concentration.

\subsection{Equipment}

In situ transesterification was performed in EMM2308X Electrolux microwave unit. The experimental equipment of in situ transesterification by microwave is illustrated in Fig. 1.

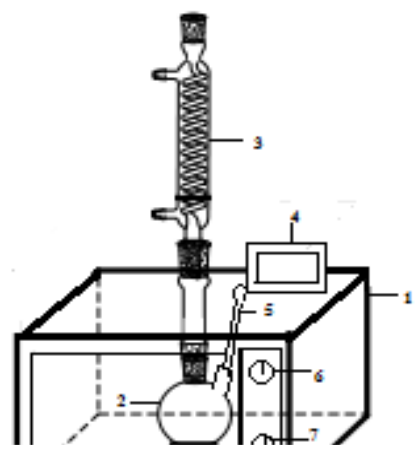

Note:

1. Microwave

2. Round neck flask

3. Condensor

4. Temperature monitor

5. Thermometer couple

6. Power controller

7. Time controller
Fig. 1. Equipment of In-situ transesterification

\section{Experimental Procedure}

\subsubsection{Extraction step of Microalga Oil by Microwave}

The experiment was carried out in round neck flask. The loaded amount of microalga powder was 10 gram for microalga oil extraction and the mixed solvents of hexane and methanol $(3: 2 \mathrm{v} / \mathrm{v})$ were $50 \mathrm{ml}$. Microalga powder and solvent were mixed in round neck flask. The extraction process was done at the microwave power of 600 watts, the reaction time of 60 minutes. After the extraction process by microwave irradiation was completed, the product was cooled down and separated by filter vacuum, the filtrate and residue were obtained. The residue was dissolved in the mixture of hexane and methanol to get the remaining oil. The filtrate was put into a separatory funnel and washed using $40^{\circ} \mathrm{C}$ of aquadest. After that, the filtrate was distilled to separate the solvent and microalga oil. Microalga oil was analyzed by gas chromatography-mass spectroscopy (GC-MS).

\subsubsection{Step of Biodiesel Production from Microalga Chlorella sp. by in situ Microwave-Assisted Transesterification}

The experimental equipment of in situ transesterification by microwave is illustrated in Fig. 1. In situ transesterification was took place in round neck flask. The loaded amount of microalga powder was 10 gram and methanol was $150 \mathrm{ml}$ for all experiments. Microalga powder and methanol was mixed in round neck flask. In situ transesterification was done at the microwave power of $300,450,600$ watt, reaction time of $30,60,90,120$ minutes, the acid catalyst concentration of $0.2 ; 0.35 ; 0.5 \mathrm{M}$ of $\mathrm{H}_{2} \mathrm{SO}_{4}$. In situ transesterification with co-solvent (nhexane) was performed in the addition of co-solvent (nhexane) was $10 \mathrm{ml}$. This process was done at the microwave power of 450 watts, acid catalyst concentration of $0.2 \mathrm{M}$ of $\mathrm{H}_{2} \mathrm{SO}_{4}$, and reaction time of $30,60,90$ and 120 minutes. After the in situ transesterification was completed, the product was cooled down and separated by filter vacuum so that, the filtrate and residue were obtained. The residue was dissolved in the mixture of hexane and methanol to get the remaining FAME. The filtrate was put into a separatory funnel then $n$-hexane was added into the funnel $(1: 1 \mathrm{v} / \mathrm{v})$, so it formed two layers. The top layer was washed using $40^{\circ} \mathrm{C}$ of aquadest then it was distilled to separate the n-hexane from crude biodiesel (product). Crude biodiesel was analyzed by gas chromatography-mass spectroscopy (GC-MS).

\section{Results and Discussion}

Experiments were carried out in round neck flask under the microwave irradiation. In-situ transesterification was done with and without the addition of co-solvent (n-hexane) using $\mathrm{H}_{2} \mathrm{SO}_{4}$ as the acid catalyst. The use of $\mathrm{H}_{2} \mathrm{SO}_{4}$ in this process will give several advantages, those are not sensitive to the content of FFA and water in oil, esterification and transesterification can take place simultaneously, and saponification can be avoided. Biodiesel yield was defined as the mass of crude biodiesel divided by the mass of microalga oil.

\subsection{GC-MS Characterization of Microalga Oil}

Based on the experiment, the yield of microalga oil extraction was $11.37 \%$ (based on its dry weight). GCMS analysis shows that fatty acid compounds of microalga oil consist of saturated fatty acid group such as palmitic acid (C16:0), stearic acid (C18:0); monounsaturated fatty acid group such as oleic acid (C18:1); and polyunsaturated fatty acid grup such as linoleic acid (C18:2) with total of area reach $22.53 \%$ of $\%$ area of the sample. Table 1 . shows the fatty acid compounds of microalga oil based on the GC-MS analysis. 
Table 1. Fatty acid compounds of microalga oil based on $22.53 \%$ of $\%$ area of the sample

\begin{tabular}{lcc}
\hline \multicolumn{1}{r}{ Fatty Acid } & Formula & Area (\%) \\
\hline Palmitic Acid & $\mathrm{C}_{16} \mathrm{H}_{32} \mathrm{O}_{2}$ & 43.44 \\
\hline Linoleic Acid & $\mathrm{C}_{18} \mathrm{H}_{30} \mathrm{O}_{2}$ & 6.35 \\
\cline { 2 - 3 } Oleic Acid & $\mathrm{C}_{18} \mathrm{H}_{34} \mathrm{O}_{2}$ & 44.33 \\
\cline { 2 - 3 } & $\mathrm{C}_{18} \mathrm{H}_{36} \mathrm{O}_{2}$ & 5.86 \\
Stearic Acid & \multicolumn{2}{c}{49.30} \\
\hline Total of SFA & \multicolumn{2}{c}{44.33} \\
\hline $\begin{array}{l}\text { Total of } \\
\text { MUFA }\end{array}$ \\
\hline \multicolumn{2}{c}{6.35} \\
Total of \\
PUFA
\end{tabular}

This analysis fits with the research by Harrington (1986) [10]. He has been reported that all plants oil which is used for biodiesel production must contain $\mathrm{C} 16$ and $\mathrm{C} 18$ of fatty acids. Based on this result, Chlorella sp. is a potential feedstock for biodiesel production.

\subsection{Effect of Reaction Time and Microwave Power}

Fig. 2 shows the effect of reaction time and microwave power on yield of crude biodiesel at various acid catalyst concentration. At the various concentration of $0.2 ; 0.35 ; 0.5 \mathrm{M}$, in situ transesterification was done effectively at the microwave power of 450 watts. Microwave power affects in the increase and the stability of temperature. The most instability of temperature occurred at the microwave power of 300 watts. According to the experiments, the microwave power of 600 watts resulted in the highest temperature reaction compared to microwave power of 300 and 450 watts. Increasing of temperature will help to the breakdown of microalga cell wall, but excessive using of power and heating result in the overheating for reaction and little oil will burn [11]. Besides it, at higher temperature methanol will evaporate and can disturb the transesterification [12]. Addition, three of graphics above have almost the same tren. At 300 watt, the yield of crude biodiesel increased at the reaction time range of 30-90 minutes. At 450 watt, the yield of crude biodiesel increased at the reaction time range of 30-60 minutes. At 600 watt, the yield of crude biodiesel increased at the reaction time range of 30-60 minutes and at 0,35 and 0,5 $\mathrm{M}$ of catalyst concentration while the yield of crude biodiesel increased at the reaction time range of 30-90 minutes and catalyst concentration of $0,2 \mathrm{M}$. The highest yield of crude biodiesel was $65 \%$. It was obtained at the microwave power of 450 watts and the reaction time of 60 minutes. This experiments also show that effective microwave power for in-situ transesterification was 450, 600 and 300 watt, respectively.

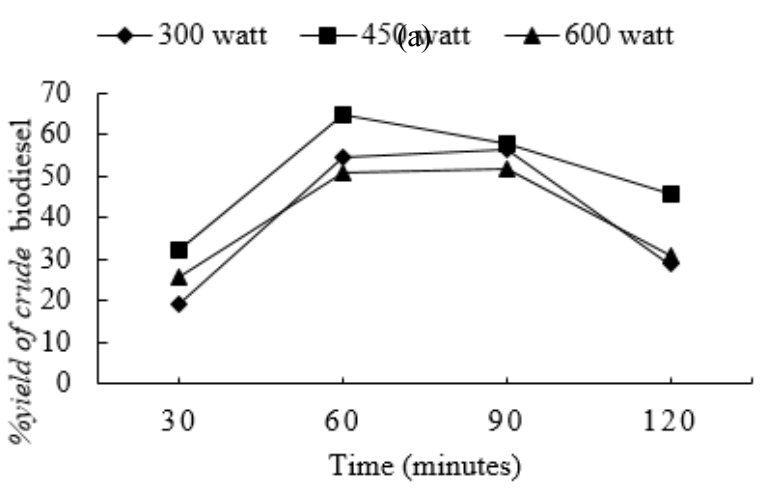

(a) Acid catalyst concentration of $0.2 \mathrm{M} \mathrm{H}_{2} \mathrm{SO}_{4}$

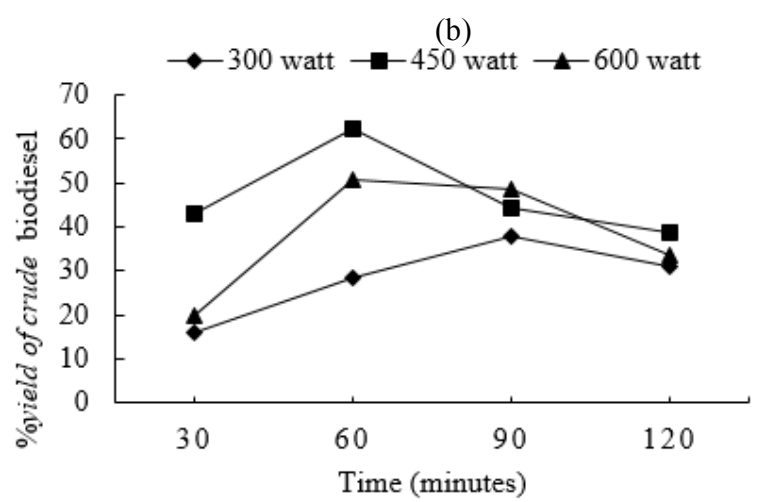

(b) Acid catalyst concentration of $0.35 \mathrm{M} \mathrm{H}_{2} \mathrm{SO}_{4}$

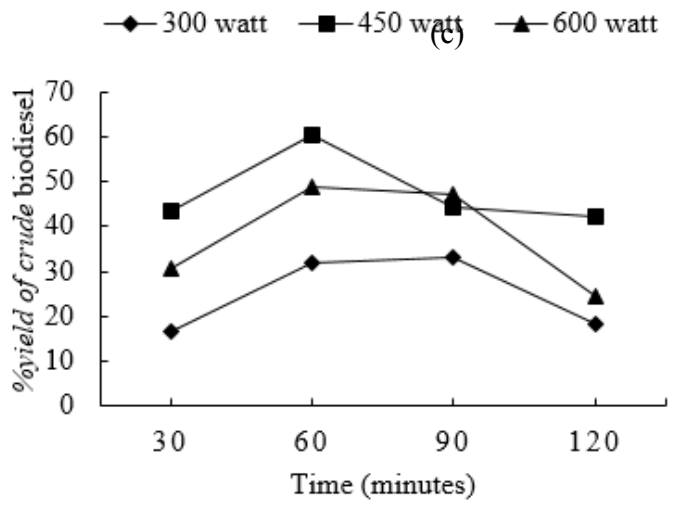

(c) Acid catalyst concentration of $0.5 \mathrm{M} \mathrm{H}_{2} \mathrm{SO}_{4}$

Fig. 2. The effect of reaction time and microwave power on yields at catalyst concentration (a) $0.2 \mathrm{M} \mathrm{H}_{2} \mathrm{SO}_{4}$; (b) 0.35 $\mathrm{H}_{2} \mathrm{SO}_{4}$; (c) $0.5 \mathrm{M} \mathrm{H}_{2} \mathrm{SO}_{4}$.

\subsection{Effect of catalyst concentration and reaction time}

In addition, Fig. 3 shows the effect of the reaction time of 30, 60,90 and 120 minutes on the yield of crude biodiesel at the acid catalyst concentration of $0.2 ; 0.35$; 
$0.5 \mathrm{M}$ of $\mathrm{H}_{2} \mathrm{SO}_{4}$ and effective microwave power of 450 watts. Acid catalyst concentration and reaction time give varied influence on in situ transesterification. At the reaction time of 30 minutes, the yield of crude biodiesel increased with the higher catalyst concentration. At the reaction time of 60,90 , and 120 minutes, and catalyst concentration of $0.35 \mathrm{M}$ and $0.5 \mathrm{M}$, the yield of crude biodiesel was lower compared to catalyst concentration of $0.2 \mathrm{M}$. This occurred because of the negative effect of acid catalysts with high concentrations that can cause side reaction which is called an alcohol dehydration[13].

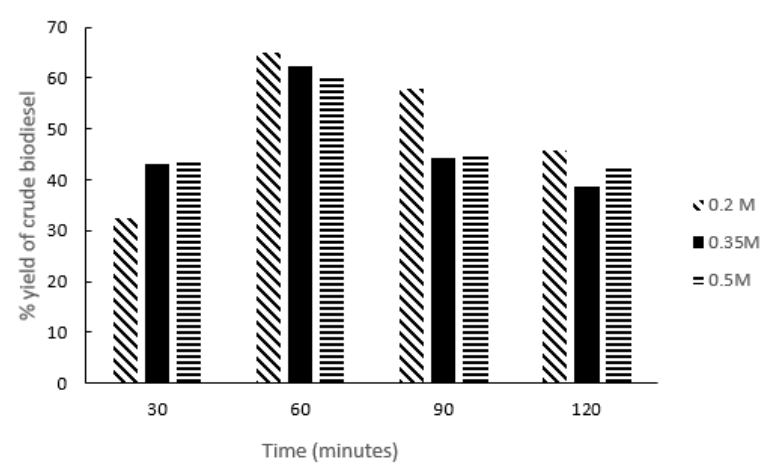

Fig. 3. The effect of catalyst concentration and reaction time on yield at the microwave power of 450 watts.

\subsection{Effect of addition of co-solvent}

Fig. 4, shows a comparison of yield with and without the addition of co-solvent in in-situ transesterification. The yield of crude biodiesel increased with the addition of co-solvent (n-hexane). It occurs because co-solvent can increase the solubility of oil in methanol [14]. Cosolvent also can reduce the interfacial surface tension of oil and methanol leading to form one phase of the liquid mixture. This condition increases the contact between reactants [15]. The highest yield of crude biodiesel was $75.68 \%$. It was obtained at the microwave power of 450 watts and the reaction time of 60 minutes, the catalyst concentration of $0.2 \mathrm{M}$ and the addition of co-solvent was $10 \mathrm{ml}$.

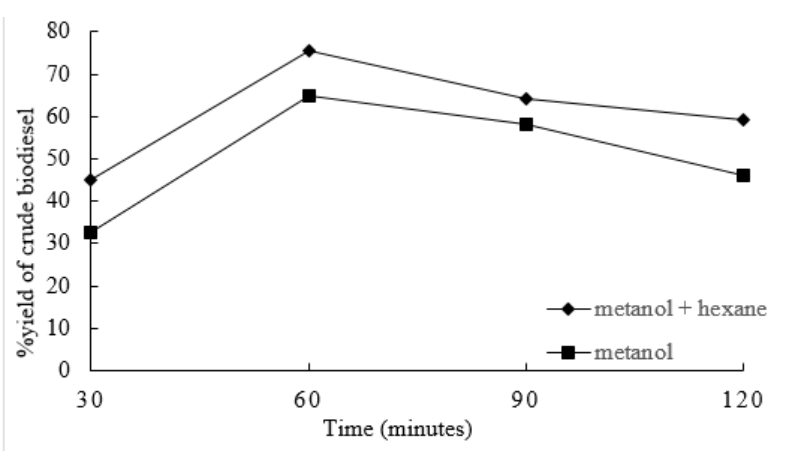

Fig. 4. The comparison of in situ transesterification with and without of co-solvent. The operation conditions at the microwave power of 450 watts and catalyst concentration of $0.2 \mathrm{M} \mathrm{H}_{2} \mathrm{SO}_{4}$

\subsection{FAME compounds of Chlorella sp.}

Based on GC-MS analysis, the main compounds of methyl ester of biodiesel were palmitic acid (C16:0), palmitoleic acid (C16:1), myristic acid (C14:0), eicosapentaenoic acid (C20:5) and oleic acid (C18:1) and the total area reach $88,94 \%$ of $\%$ FAME normalization. Total of $\%$ FAME normalization on biodiesel sample was $35.09 \%$. FAME compounds of biodiesel are presented in Table 2 .

Table 2. Methyl ester compounds of Chlorella sp. based on $35,09 \%$ of $\%$ FAME area of biodiesel sample

\begin{tabular}{|c|c|c|}
\hline $\begin{array}{c}\text { Methyl Ester } \\
\text { (FAME) }\end{array}$ & Formula & Area (\%) \\
\hline $\begin{array}{c}\text { lauric acid methyl } \\
\text { ester }\end{array}$ & $\mathrm{C}_{13} \mathrm{H}_{26} \mathrm{O}_{2}$ & 1.08 \\
\hline $\begin{array}{l}\text { E-11-tetradecanoic } \\
\text { acid methyl ester }\end{array}$ & $\mathrm{C}_{15} \mathrm{H}_{28} \mathrm{O}_{2}$ & 0.49 \\
\hline $\begin{array}{c}\text { myristic acid methyl } \\
\text { ester }\end{array}$ & $\mathrm{C}_{15} \mathrm{H}_{30} \mathrm{O}_{2}$ & 11.10 \\
\hline $\begin{array}{c}\text { pentadecanoic acid } \\
\text { methyl ester }\end{array}$ & $\mathrm{C}_{16} \mathrm{H}_{32} \mathrm{O}_{2}$ & 0.65 \\
\hline $\begin{array}{l}\text { palmitoleic acid } \\
\text { methyl ester }\end{array}$ & $\mathrm{C}_{17} \mathrm{H}_{32} \mathrm{O}_{2}$ & 25.50 \\
\hline $\begin{array}{c}\text { palmitic acid methyl } \\
\text { ester }\end{array}$ & $\mathrm{C}_{17} \mathrm{H}_{34} \mathrm{O}_{2}$ & 35.04 \\
\hline $\begin{array}{l}\text { Z-7- hexadecanoic } \\
\text { acid methyl ester }\end{array}$ & $\mathrm{C}_{17} \mathrm{H}_{32} \mathrm{O}_{2}$ & 1.18 \\
\hline $\begin{array}{c}\text { margaric acid methyl } \\
\text { ester }\end{array}$ & $\mathrm{C}_{18} \mathrm{H}_{36} \mathrm{O}_{2}$ & 0.49 \\
\hline $\begin{array}{l}\text { 8,11-octadecanoic } \\
\text { acid methyl ester }\end{array}$ & $\mathrm{C}_{19} \mathrm{H}_{34} \mathrm{O}_{2}$ & 1.53 \\
\hline $\begin{array}{l}\text { oleic acid methyl } \\
\text { ester }\end{array}$ & $\mathrm{C}_{19} \mathrm{H}_{36} \mathrm{O}_{2}$ & 6.33 \\
\hline $\begin{array}{l}\text { 11-octadecanoic } \\
\text { methyl ester }\end{array}$ & $\mathrm{C}_{19} \mathrm{H}_{36} \mathrm{O}_{2}$ & 0.60 \\
\hline $\begin{array}{c}\text { stearic acid methyl } \\
\text { ester }\end{array}$ & $\mathrm{C}_{19} \mathrm{H}_{36} \mathrm{O}_{2}$ & 2.11 \\
\hline $\begin{array}{c}\text { 10-nonadecanoic acid } \\
\text { methyl ester }\end{array}$ & $\mathrm{C}_{20} \mathrm{H}_{38} \mathrm{O}_{2}$ & 0.49 \\
\hline
\end{tabular}




\begin{tabular}{|c|c|c|}
\hline $\begin{array}{l}\text { arachidonic acid } \\
\text { methyl ester }\end{array}$ & $\mathrm{C}_{21} \mathrm{H}_{42} \mathrm{O}_{2}$ & 2.43 \\
\hline $\begin{array}{l}\text { Eicosapentaenoic } \\
\text { acid methyl ester }\end{array}$ & $\mathrm{C}_{21} \mathrm{H}_{32} \mathrm{O}_{2}$ & 10.97 \\
\hline Total of SFA & & 52.91 \\
\hline Total of MUFA & & 34.59 \\
\hline Total of PUFA & & 12.50 \\
\hline
\end{tabular}

\section{Conclusions}

In situ transesterification was studied by microwave irradiation at microwave power of 300, 450, 600 watt, reaction time of $30,60,90,120$ minutes, acid catalyst concentration of $0.2 ; 0.35 ; 0.5 \mathrm{M}$ of $\mathrm{H}_{2} \mathrm{SO}_{4}$ while in situ transesterification with co-solvent at microwave power of 450 watt, acid catalyst concentration of $0.2 \mathrm{M}$ of $\mathrm{H}_{2} \mathrm{SO}_{4}$, and reaction time of $30,60,90$ and 120 minutes. The highest yield of crude biodiesel was $75.68 \%$. It was obtained at the microwave power of 450 watts, the reaction time of 60 minutes, the catalyst concentration of $0.2 \mathrm{M}$ and the addition of co-solvent was $10 \mathrm{ml}$. The yield of biodiesel was influenced by microwave power, reaction time, acid catalyst concentration and co-solvent. A longer of reaction time and a greater of power provided a higher of biodiesel yield. However, when the condition reaches in optimum condition, the longer of reaction time and the greater of power, provide the lower of biodiesel yield. The addition of co-solvent (n-hexane) in in-situ transesterification gives the higher of biodiesel yield. The main compounds of methyl ester were palmitic acid methyl ester and palmitoleic acid methyl, respectively.

\section{References}

1. J. Basmal. Squalen 3(1) (2008)

2. V.Feddern. Embrapa Swine and Poultry (Brazil, 2015)

3. Christi,Y. Advances 11, 294-306 (2007)

4. M. Latief. ResearchGate. (to be published)

5. K.K. Sharma, H. Schuhman, P.M. Schenk. Energies 5 (5), 1532-1553 (2012)

6. J. Liu, Z. Sun, H. Gerken. OMICS Group eBooks (USA, 2016)

7. S. Yucel, P. Tergiozglu. 2013. Recent Res. Devel. Lipids 9, 101-124 (2013)

8. N. Azcan, O. Yilmaz. Proceedings of the World Congress on Engineering and Computer Science Vol II (San Francisco, USA, 2012)

9. Dianursanti, P. Religia, A. Wijanarko. (2015). Procedia E.S 23, 412 - 420 (2015)

10. K.J Harrington. 1986. Biomass 9, 1-17 (1986)

11. P. Li, X. Miao, R. Li, and J. Zhong. Hindawi 2011, 1-8 (2011)

12. Y. Tang, Y. Zhang, J. Rosenberg, M. Betenbaugh, F. Wang. Appl. Sci 6, 343 (2016)

13. P.M. Ejikeme, I.D. Anyaogu, C.L. Ejikeme, N.P. Nwafor, C.A. Egbuonu, K. Ukogu, J.A. Ibemesi. J. Chem 7(4), 1120-1132 (2010)

14. V.T. Wyatt, M.J. Haas. J. Am. Oil Chem. Soc 86, 1009-1016 (2009)

15. D.S. Khang, F.R. Luis, F.M. Cynthia, R.T. Raymond. Chem. Eng. R \& D 92, 1512-1518 (2014) 